\title{
Increasing Conjugated Linoleic Acid Content in Milk and Cheese after Supplementing a Blend of Crude Soybean Oil Sediment Combined with Fish Oil to Grazing Dairy Cows
}

\author{
Gerardo Antonio Gagliostro ${ }^{1}$, Liliana Elisabet Antonacci ${ }^{1}$, Carolina Daiana Pérez ${ }^{2,3}$, \\ Luciana Rossetti2, Martín Tassone ${ }^{4}$, Verónica Frossasco4, Favio Terreno4, \\ Alvaro Ugartemendia ${ }^{4}$
}

\author{
${ }^{1}$ Instituto Nacional de Tecnología Agropecuaria (INTA), Estación Experimental Balcarce, Area de Producción Animal, Balcarce, \\ Argentina \\ ${ }^{2}$ Instituto de Tecnología de Alimentos (ITA), CNIA INTA, Castelar, Argentina \\ ${ }^{3}$ Consejo Nacional de Investigaciones Científicas y Técnicas (CONICET), Buenos Aires, Argentina \\ ${ }^{4}$ Establecimiento Agroindustrial Capilla del Señor S.A., Villa María, Provincia de Córdoba, Argentina \\ Email: gagliostro.gerardo@inta.gob.ar
}

How to cite this paper: Gagliostro, G.A., Antonacci, L.E., Pérez, C.D., Rossetti, L., Tassone, M., Frossasco, V., Terreno, F. and Ugartemendia, A. (2020) Increasing Conjugated Linoleic Acid Content in Milk and Cheese after Supplementing a Blend of Crude Soybean Oil Sediment Combined with Fish Oil to Grazing Dairy Cows. Open Journal of Animal Sciences, 10, 468-492. https://doi.org/10.4236/ojas.2020.103029

Received: February 1, 2019

Accepted: June 21, 2020

Published: June 24, 2020

Copyright $\odot 2020$ by author(s) and Scientific Research Publishing Inc. This work is licensed under the Creative Commons Attribution International License (CC BY 4.0).

http://creativecommons.org/licenses/by/4.0/ (c) (i) Open Access

\begin{abstract}
The aim of the work was to improve the healthy value of milk and cheese fatty acids (FA) by feeding a mix of crude soybean oil sediment (CSOS) combined with fish oil (FO) to grazing dairy cows. The CSOS is a by-product commonly discarded after oil extraction containing 3.3\% moisture, $6 \%$ total ash and $70.7 \%$ oil, locally available, comparatively economic and easy to mix with other feed ingredients. The experiment lasted 55 days from September $30^{\text {th }}$ to November $23^{\text {th }} 2018$ and was carried out at the dairy farm "Gacef" provider of milk to the dairy industrial plant "Capilla Del Señor" (CDS) located at the Villa María City, Córdoba Province, Argentine. A herd of 80 multiparous Holstein cows producing $24 \mathrm{~kg}^{-1}$ milk.cow ${ }^{-1} \cdot \mathrm{day}^{-1}$ was used. The cows grazed an alfalfa and an oat pasture that represented about $47 \%$ of total dry matter $(\mathrm{DM})$ intake supplemented at $8.5 \mathrm{~kg} \mathrm{DM} \cdot \mathrm{cow}^{-1} \cdot \mathrm{day}^{-1}$ with a total mixed ration (TMR) composed (DM basis) by cracked corn grain $(35.18 \%$ ), whole plant corn silage (31.98\%), pelletized soyben meal (17.99\%), the CSOS supplement $(13.85 \%)$ and FO $(0.99 \%)$. The TMR was supplied by halves after each milking time in groupal feeders yielding $1.4 \mathrm{~kg} \cdot \mathrm{cow}^{-1} \cdot \mathrm{day}^{-1}$ of the CSOS and $0.1 \mathrm{~kg} \cdot \mathrm{cow}^{-1} \cdot \mathrm{day}^{-1}$ of FO. Before the start of lipid supplementation, milk samples (5) were obtained from the farm-tank representing the standar or reference milk (Ref-Milk). After 21 days of supplementary lipid supply, additional milk samples (5) were obtained representing the modified milk
\end{abstract}


(Mod-Milk). Milk samples were analyzed for chemical composition and milk FA profile. At each time, sufficient quantities of both (Ref- and Mod-Milk) were collected for manufacturing six types of cheeses. The results were analyzed through the Sudent-T test for independent observations. Oil supplementation did not modify $(P>0.05)$ the chemical composition of milk. Concentration of butyric acid $\left(\mathrm{C}_{4: 0}\right)$ in milk was not affected $(P<0.858)$. Concen-

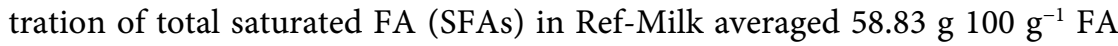

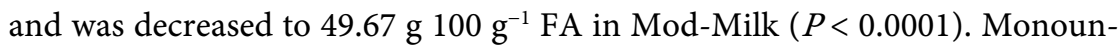

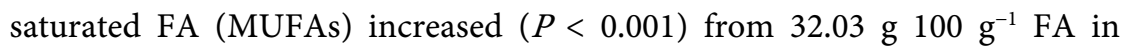

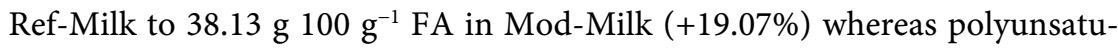
rated FA (PUFAs) increased $(+36.1 \%)$ from 4.71 to $6.41(P<0.004)$. The

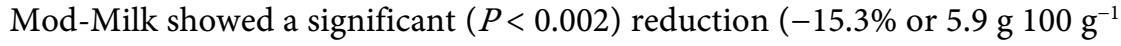
FA) for the total concentration of the potentially atherogenic fraction of milk FA $\left(\mathrm{C}_{12: 0}\right.$ to $\left.\mathrm{C}_{16: 0}\right)$. The atherogenic index $(\mathrm{AI})$ also decreased $(P<0.012)$ from 1.98 in Ref-Milk to 1.42 in Mod-Milk (-28.4\%). Concentration of vaccenic

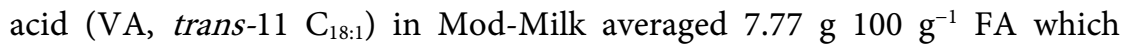
represented a $162 \%$ increase $(P<0.0001)$ over that observed in Ref-Milk

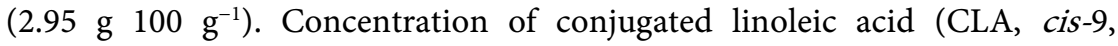
trans-11 $\left.\mathrm{C}_{18: 2}\right)$ in Ref-Milk averaged $1.47 \mathrm{~g} 100 \mathrm{~g}^{-1} \mathrm{FA}$ and showed an impor-

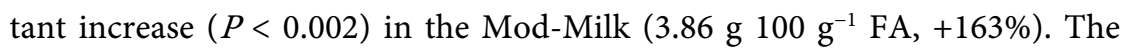
omega 6/3 ratio resulted lower $(P<0.012)$ in the Ref-Milk $(2.28)$ compared to the Mod-Milk (2.83). Milk and cheese FA composition were highly correlated $\left(\mathrm{R}^{2}=0.99, P<0.0001\right)$. The Mod-Cheeses showed similar results in AI, total concentration of SFAs, MUFAs and PUFAs compared to the milk of origin. Differences in FA composition between the cheeses made with the Ref- and Mod-Milk were equivalent to those described for milks. It is concluded that supplementation with a blend of CSOS supplement and FO was an effective way to improve the healthy value of dairy products by reducing contents of SFAs, atherogenic FAs and the atherogenicity index with a concomitant increase in VA and CLA. Modifications induced in the Mod-Milk were recovered in the Mod-Cheeses. The results obtained may help to reduce saturated fat intake and fight or prevent incidence of non-communicable, cardiovascular and chronic diseases.

\section{Keywords}

Oil Supplementation, Grazing Dairy Cow, Milk Fatty Acids, Conjugated Linoleic Acid, Cheese, Fish Oil, Crude Soybean Oil Sediment

\section{Introduction}

The FA composition of milk fat is an important factor determining its healthy value due to the potential effects that specific FAs have on the consumer's health. Bovine milk fat may contain up to $70 \%$ SFAs which could exert negative effects when consumed in excess, as well as 25\% of MUFAs and 5\% PUFAs both of which have potential positive effects on human health [1] [2] [3]. 
Dairy fat is also a determinant component for the technological quality of milk since together with the protein fraction affects the efficiency of cheese yield and the sensory properties of the dairy products. Milk FAs may be positively or negatively involved with human health [1] [2] [3] [4] and therefore merit some concern. The increasing incidence of non-communicable, cardiovascular and chronic diseases in the modern society implies an economic and social burden for countries generating the need to produce foods capable of mitigating these risks.

Milk fat represents up to $75 \%$ of the total fat intake of animal origin contributing between $25 \%$ to $35 \%$ of the total SFAs consumed by humans being the target of criticism by specialists in human nutrition [1] which explains in part the decreased intake of dairy products [5] [6].

Recent studies have shown that SFAs intake can be even healthier than consuming a high amount of carbohydrates in the so-called low-fat diets [7] [8]. As excessive SFAs intake is still considered to play a putative role in the development of chronic cardiovascular diseases, obesity and metabolic síndrome [4] [9] [10] [11] reductions in the amount of SFAs in food still which represents a global-healthy priority [12].

Certain SFAs from milk fat such as lauric $\left(\mathrm{C}_{12: 0}\right)$, myristic $\left(\mathrm{C}_{14: 0}\right)$ and palmitic $\left(\mathrm{C}_{16: 0}\right)$ are classed as potentially atherogenic if consumed in excess [5] [13]. Their concentration in dairy foods can be naturally reduced by feeding supplementary oils rich in PUFAs to dairy cows [1] [14] [15] [16]. In ruminants, PUFAs intake is known to inhibit de novo mammary synthesis of $\mathrm{C}_{12: 0}$ to $\mathrm{C}_{16: 0}$, reducing its $\mathrm{AI}$ and further increasing the levels of healthy FA like VA and CLA [1] [14] [15] [16].

Several studies have shown that the consumption of dairy products can decrease the cardiovascular risk factors or the metabolic syndrome [17] [18]. The natural isomer of CLA, the cis-9, trans-11- $\mathrm{C}_{18: 2}$ also called rumenic acid, can only be found in meat and milks from ruminant animals and have shown a special interest for its role as a regulator of the levels and composition of plasma lipids and aortic ischemia [19], a reduction of certain types of cancer, blocking tumor growth activity and reduce breast cancer metastasis demonstrated in vitro or in animal experiments [20] [21] [22].

In human beings, an intervention study showed that the consumption of a pecorino-CLA cheese enriched with natural CLA induced favorable biochemical changes in atherosclerosis markers [23]. Another intervention study showed that concentration of CLA in human adipose tissue provided by milk was associated with a lower risk of nonfatal myocardial infarction in the population of Costa Rica and that the consumption of dairy products was not associated with the risk of this type of heart attack [18]. The authors concluded that the potential protective beneficial effect of CLA on heart attack would also outweigh the putative adverse effects of SFAs present in dairy products [18].

Taken together, properties of the different FAs on human health explain the 
interest of nutritionist in naturally modulating milk FAs profile through natural ways to produce healthier and natural dairy foods. The regular consumption of naturally occurring VA and CLA derived from dairy products may be beneficial in reducing lipid risk factors associated with cardiovascular disease and other health threats.

The main precursor of the natural CLA is the trans-11 isomer of $\mathrm{C}_{18: 1}$ or vaccenic acid (VA) which has showed direct anticarcinogenic properties in itself or mediated by its conversion to CLA in human tissues [24] at an average rate of $20 \%$ [25]. Dairy fat is the main natural source of VA and CLA and the concentration of these two healthy FAs in milk and hence in dairy foods, is highly dependent on the type of diet and strategic supplementation of the dairy cows [1] [14].

Pasture based diets allows to obtain milks rich in basal CLA contents but considerable increases may be further obtained after supplementation with PUFAs-rich vegetable oils [1] [14]. An additional and effective strategy to increase VA and CLA and reduce SFAs contents is the inclusion of FO in the ration of cows [1] [16]. This oil is rich in long-chain PUFAs such as eicosapentanoic acid or EPA $\left(\mathrm{C}_{20: 5 c i s-5, c i s-8, c i s-11, c i s-14, c i s-17}\right)$ and docohexaenoic acid or DHA

$\left(\mathrm{C}_{22: 6 c i s-4, c i s-7, c i s-10, c i s-13, c i s-19, c i s-19}\right)$ that reduce the rumen microbial activity associated to biohydrogenation of VA, the main precursor for CLA synthesis [1] [26]. Recycling the CSOS via cows feeding is considered as friendly to the environment since all irrational discarding of this product after oil extraction is potentially polluting and lipid supplementation has also showed to be an effective tool to reduce the emission of enteric methane by ruminants [27].

The aim of the present study was to explore the effect of supplementation with a CSOS supplement combined with FO as a natural strategy to improve the healthy value of the milk and cheese FA currently produced in a comercial dairy agroindustrial complex. Special emphasis was focused on reducing the total amount of SFAs and the hypercholesterolemic fraction of milk fat while increasing the concentration of the healthy VA and RA.

\section{Materials and Methods}

\subsection{Cows and Diets}

The work was carried out at the "Gacef Farm", a comercial dairy establishment that supplies the CLA enriched milk to the Agroindustrial Factory "Capilla del Señor" (CDS, http://www.lacteoscds.com.ar/) located at the Villa María City, Córdoba Province, Argentine. At the same time, CDS manufacture the "LacNat" cheeses.

The experiment lasted 55 days during spring-time from September $30^{\text {th }}$ to November $23^{\text {th }} 2018$ and was carried out using a herd of eighty (80) multiparous Holstein dairy cows averaging 24 liters $\cdot \operatorname{cow}^{-1} \cdot$ day $^{-1}$ at the start of the trial. The whole available cows of the farm were used in order to collect a sufficient volume of milk to make the cheeses at the commercial CDS plant.

Cows grazed an alfalfa and an oat pastures in two daily grazing shifts. Pasture 
intake accounted for approximately $47.34 \%$ of total DM intake. The cows were supplemented with $8.5 \mathrm{~kg} \mathrm{DM} \cdot \mathrm{cow}^{-1} \cdot \mathrm{day}^{-1}$ of a total mixed ration (TMR) composed (DM basis) by cracked corn grain (35.18\%), whole plant corn silage (31.98\%), pelletized soyben meal (17.99\%), the CSOS supplement (13.85\%) and FO (0.99\%). The TMR (57.17 DM) was made using a mixer wagon and supplied by halves after each milking time in groupal feeders. On a DM basis, it contained $12.87 \%$ crude protein, 24.39 neutral detergent fiber (NDF), 14.12\% acid detergent fiber (ADF), and $2.93 \mathrm{Mcal} / \mathrm{kg} \mathrm{DM}$ of metabolizable energy.

The CSOS remains stable for about six months if stored in a cool and dark environment. To obtain this by-product and before oil extraction, the soybean grain is adjusted to $11 \%$ moisture, broken and processed with an extruder screw, pressed by friction to extract the oil separating it from the protein fraction. The hot expeller is then cooled and driven to a storage silo. For its part, the oil obtained from the press is filtered with a very fine mesh to separate the solid particles and led to a storage tanke where sedimentation and accumulation of CSOS takes place at the bottom of the tank. The CSOS contained about $96.7 \%$ DM, 94\% organic matter and 70.7\% oil (Extraction with solvent, modified Folch and gravimetry). The use of the CSOS in dairy cows feeding is compatible with the objective of not contaminating the environment.

The FA profile of the CSOS supplement showed $0.12 \%( \pm 0.04)$ of myristic acid $\left(\mathrm{C}_{14: 0}\right), 10.54 \%( \pm 0.08)$ of palmitic acid $\left(\mathrm{C}_{16: 0}\right), 4.59 \%( \pm 0.05)$ of stearic acid $\left(\mathrm{C}_{18: 0}\right), 20.47 \%( \pm 0.34)$ of oleic acid $\left(\right.$ cis-9 $\left.\mathrm{C}_{18: 1}\right), 53.04 \%( \pm 0.01)$ of linoleic acid (cis-9, cis-12 $\left.\mathrm{C}_{18: 2 \mathrm{n}-6}\right)$ and 7.66\% ( \pm 0.02$)$ of linolenic acid $\left(\mathrm{C}_{18: 3 n-3}\right)$ with an $\mathrm{n}-6 / \mathrm{n}-3$ ratio of 6.93. This FAs composition of the CSOS is considered as highly adequate to raise milk CLA content at a realtively low feeding cost (about $45 \mathrm{U} \$ \mathrm{D} / \mathrm{Ton}$ ) if compared to SO (755 U\$D/Ton) with similar levels of linoleic (55.38\%) and linolenic (7.53\%) acids as precursors of VA and CLA. On the other hand, FO showed 20.15\% $( \pm 0.77)$ of $\mathrm{C}_{16: 0}, 2.63 \%( \pm 0.09)$ of $\mathrm{C}_{18: 2}, 1.41 \%( \pm 0.08)$ of $\mathrm{C}_{18: 3}$, $10.92 \%( \pm 2.14)$ of $\mathrm{C}_{20: 5}(\mathrm{EPA})$ and $21.64 \%( \pm 0.42)$ of $\mathrm{C}_{22} 6$ (DHA).

\subsection{Samples Collection and Analysis}

Milk samples (5) from the collecting tank were obtained prior to the start of lipid supplementation to determine the basal chemical composition and FAs profile of the Ref-Milk. Another 5 samples were collected at day $21^{\text {th }}$ after the start of lipid supplementation to obtain the CLA rich Mod-Milk. Before lipid supplementation, sufficient quantities of the basal Ref-Milk were collected to elaborate the Ref-Cheeses and from day $22^{\text {th }}$ and during a 30 days period of lipid supplementation, the Mod-Milk was collected for the elaboration of six types of cheeses according to the technology normally used in the comercial factory plant.

On each day of sampling, $100 \mathrm{ml}$ of milk were obtained of which $20 \mathrm{ml}$ were used immediately for the determination of fat, protein, lactose, non-fat solids (SNF) and total solids (TS) by spectrophotometry (Milko-Scan) and the remaining $80 \mathrm{ml}$ were immediately frozen $\left(-20^{\circ} \mathrm{C}\right)$ until analysis of milk FA pro- 
file in the laboratory of the Institute of Food Technology (ITA, INTA-Castelar) as described in [28]. Ref- and Mod-Cheese types were also analyzed for its FA pofile and total colesterol content based on samples of $250 \mathrm{~g}$ of each product made with the Ref-Milk and the Mod-Milk.

\subsection{Statistical Analysis}

The difference in chemical composition and FA profile were analyzed through the Student's $T$ test for independent observations.

\section{Results and Discussion}

\subsection{Milk Composition}

The chemical composition of milk samples taken before and after the start of lipid supplementation is presented in Table 1 .

Supplementary PUFAs intake from CSOS and FO oil did not affect the chemical composition of milk and therefore its industrial aptitude for cheese making. Supplementation with PUFAs to dairy cows in pasture-based diets usually reduces milk fat content by $8 \%$ [29] a result not observed in the present trial (Table 1). The DHA contained in the FO is a potent inhibitor of de novo mammary lipogenesis. This fact, and the ruminal generation of certain FAs such as trans-10 $\mathrm{C}_{18: 1}$ after PUFAs supplementation and its subsequent transfer to the udder, often decrease milk fat content.

A direct relationship between increasing levels of trans-10 $\mathrm{C}_{18: 1}$ in milk and the reduction of de novo mamary synthesis has been reported [30] which may explain in part a drop in milk fat content. The presence of trans-10 $\mathrm{C}_{18: 1}$ has been associated with dysfunctions in the activity of the enzymes lipoprotein lipase (LPL) and stearyl CoA desaturase (SCD) involved in the synthesis of fat thus causing a decrease in milk fat content [31]. In the present trial, both the concentration of trans-10 $\mathrm{C}_{18: 1}$ and that of DHA in milk were very low (Table 2) may have contributed in part to explain the lack of effect of PUFAs feeding on milk fat content. In a previous work under grazing conditions [32], feeding soybean oil combined or not with FO strongly reduced milk fat content ( $-19 \%$ to $-27 \%)$.

Table 1. Parameters of chemical composition in the reference (Ref-Milk) and modified milks (Mod-Milk).

\begin{tabular}{|c|c|c|c|}
\hline 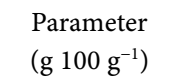 & Ref-Milk $^{(1)}$ & Mod-Milk $^{(2)}$ & $P<$ \\
\hline Fat & $3.36 \pm 0.54$ & $3.20 \pm 0.09$ & 0.49 \\
\hline Protein & $3.14 \pm 0.23$ & $3.08 \pm 0.03$ & 0.52 \\
\hline Lactose & $4.55 \pm 0.30$ & $4.68 \pm 0.04$ & 0.32 \\
\hline Total Solids & $11.79 \pm 0.83$ & $11.70 \pm 0.12$ & 0.80 \\
\hline Solids non Fat & $8.43 \pm 0.49$ & $8.50 \pm 0.07$ & 0.75 \\
\hline
\end{tabular}

${ }^{(1)}$ Tank samples obtained before the start of lipid supplementation. ${ }^{(2)}$ Tank samples obtained after 23 days of supplementation with a mix of soybean oil extrusion wrench (CSOS) and fish oil. 
Table 2. Milk fatty acid profile before (Ref-Milk) and 23 days after cows supplementation with a blend of crude soybean oil sediment combined with fish oil (Mod-Milk).

\begin{tabular}{|c|c|c|c|c|}
\hline $\begin{array}{l}\text { Fatty Acid } \\
\text { g } 100 \mathrm{~g}^{-1} \mathrm{FA}\end{array}$ & Ref-Milk & Mod-Milk & $P<^{(1)}$ & $\Delta \%^{(2)}$ \\
\hline $\mathrm{C}_{4: 0}$ & $1.96( \pm 0.18)$ & $1.97( \pm 0.08)$ & 0.858 & - \\
\hline $\mathrm{C}_{6: 0}$ & $1.74( \pm 0.06)$ & $1.43( \pm 0.16)$ & 0.010 & -17.91 \\
\hline $\mathrm{C}_{8: 0}$ & $1.20( \pm 0.04)$ & $0.89( \pm 0.14)$ & 0.005 & -26.08 \\
\hline $\mathrm{C}_{10: 0}$ & $2.76( \pm 0.09)$ & $1.89( \pm 0.35)$ & 0.003 & -31.48 \\
\hline $\mathrm{C}_{12: 0}$ & $3.14( \pm 0.04)$ & $2.13( \pm 0.35)$ & 0.001 & -32.22 \\
\hline $\mathrm{C}_{14: 0}$ & $11.89( \pm 0.54)$ & $8.61( \pm 1.0)$ & 0.001 & -27.60 \\
\hline $\mathrm{C}_{16: 0}$ & $24.95( \pm 0.11)$ & $22.26( \pm 1.11)$ & 0.003 & -10.78 \\
\hline$\sum \mathrm{C}_{12: 0}-\mathrm{C}_{16: 0}$ & $38.51( \pm 0.16)$ & $32.61( \pm 2.29)$ & 0.002 & -15.30 \\
\hline $\mathrm{C}_{18: 0}$ & $9.43( \pm 0.12)$ & $(8.21( \pm 1.42)$ & 0.140 & - \\
\hline trans-9 $\mathrm{C}_{18: 1}$ & $0.27( \pm 0.01)$ & $0.76( \pm 0.04)$ & 0.000 & +187 \\
\hline trans-10 $\mathrm{C}_{18: 1}$ & $0.41( \pm 0.06)$ & $1.21( \pm 0.19)$ & 0.000 & +194 \\
\hline trans-11 $\mathrm{C}_{18: 1}$ (vaccenic acid) & $2.95( \pm 0.08)$ & $7.77( \pm 1.52)$ & 0.001 & +162 \\
\hline cis-9 $\mathrm{C}_{18: 1}$ (oleic) & $22.96( \pm 0.37)$ & $21.50( \pm 3.08)$ & 0.381 & - \\
\hline cis-9, cis-12 $\mathrm{C}_{18: 2}$ & $2.09( \pm 0.05)$ & $1.77( \pm 0.14)$ & 0.005 & -15.42 \\
\hline cis-9, trans-11 C18:2 (CLA) & $1.47( \pm 0.02)$ & $3.86( \pm 0.95)$ & 0.002 & +163.56 \\
\hline cis- 9, trans $-12 \mathrm{C}_{18: 2}$ & $0.02( \pm 0.00)$ & $0.03( \pm 0.00)$ & 0.000 & +107.24 \\
\hline cis-9, cis-12, ci-15 $\mathrm{C}_{18: 3}$ (linolenic) & $0.82( \pm 0.01)$ & $0.52( \pm 0.09)$ & 0.001 & -37.16 \\
\hline $\mathrm{C}_{20: 5} \mathrm{n}-3$ (EPA) & $0.06( \pm 0.00)$ & $0.04( \pm 0.01)$ & 0.001 & -38.15 \\
\hline $\mathrm{C}_{22: 6} \mathrm{n}-3$ (DHA) & 0.00 & 0.03 & & - \\
\hline CLA/(CLA + VA) & $0.33( \pm 0.01)$ & $0.33( \pm 0.01)$ & 0.899 & - \\
\hline Total SFA & $58.83( \pm 0.21)$ & $49.67( \pm 1.43)$ & 0.000 & -15.57 \\
\hline Total MUFA & $32.03( \pm 0.21)$ & $38.13( \pm 1.86)$ & 0.001 & +19.07 \\
\hline Total PUFA & $4.71( \pm 0.07)$ & $6.41( \pm 0.75)$ & 0.004 & +36.10 \\
\hline Atherogenic Index & $1.98( \pm 0.02)$ & $1.42( \pm 0.21)$ & 0.002 & -28.34 \\
\hline$n-6 / n-3$ ratio & $2.28( \pm 0.05)$ & $2.83( \pm 0.11)$ & 0.012 & +24.11 \\
\hline
\end{tabular}

${ }^{(1)}$ Test T de Student for independent observations. ${ }^{(2)}$ Relative change (\%) respect to the concentration observed before the start of PUFA lipid supplementation (Ref-Milk).

As pasture represented about $47 \%$ of total DM intake and the TMR contained $32 \%$ whole plant corn silage and $24.39 \% \mathrm{NDF}$ it is also possible to infer that the amount of effective fiber was sufficiently high to maintain an adequate ruminal $\mathrm{pH}$ avoiding the usual drastic drop in milk fat content.

Milk protein content was not affected $(P=0.52)$ averaging 3.14 and $3.08 \mathrm{~g} 100$ $\mathrm{g}^{-1} \mathrm{FA}$ in the Ref- and the Mod-Milk respectively. The absence of negative effects of PUFAs intake on milk protein concentration is important since this parameter not only affects milk price but also determines the speed and quality of milk coagulation in cheese making procedures. In pasture based diets, lipid supple- 
mentation does not usually affect milk protein concentration [29] [33] while in dairy confined feeding systems this parameter is systematically affected [34] [35].

\subsection{Milk Fatty Acid Profile}

Milk FA composition before and after supplementation with the CSOS and FO is shown in Table 2.

The increase in mammary uptake of plasma triglycerides after supplementary PUFAs intake would explain the changes observed in milk FA profile between the Ref-Milk and the Mod-Milk (Table 2). These results confirm the existence of a great plasticity in milk FAs composition after supplemtation with PUFAs to dairy cows [1] [36].

Milk butyric acid $\left(\mathrm{C}_{4: 0}\right)$ concentration was not affected $(P=0.858)$ a result often reported after lipid supplementation [36]. The lack of a negative effect on this FA is of concern considering its healthy role that showed antineoplasic effects inhibiting the development of mammary carcinoma in rats [20].

Except in the case of $\mathrm{C}_{4: 0}$, which is synthesized by an independent malonyl-CoA route, the concentration of de novo synthesized FAs in the mammary gland $\left(\mathrm{C}_{4: 0}-\mathrm{C}_{15: 1}\right)$ decreased after lipid supplementation. The result may be explained at the secretory cell level by the inhibition of the activity of lipogenic enzymes such as acetyl-CoA carboxylase [1] [37]. This effect is frequently reported after PUFAs feeding to dairy cows. The inhibitory effect of supplemental PUFAs increases with chain length, degree of unsaturation and the presence of double trans bonds [1].

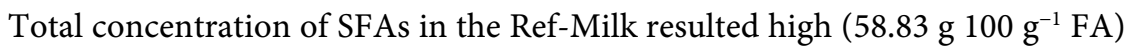

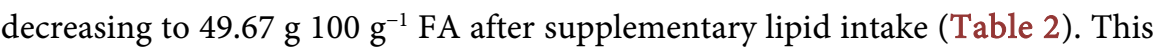
$15.57 \%$ reduction is of concern since the excessive consumption of SFAs is considered as unhealthy and therefore should be avoided. On the other hand, the

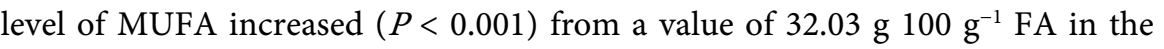

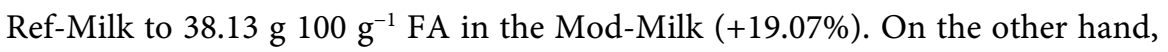
the increase in PUFAs averaged $36.1 \%$ ranging from a baseline value of $4.71 \mathrm{~g}$

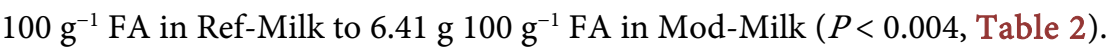

Compared to the Ref-Milk, the Mod-Milk showed a significant reduction $(15.30 \%)$ in the total concentration of the potentially atherogenic $\mathrm{FAs}\left(\mathrm{C}_{12: 0}\right.$ to

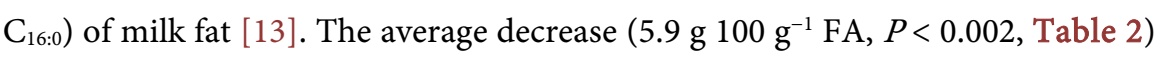
satisfies one of the functionality criterions of the Mod-Milk that includes a reduction of potentially unhealthy FAs in milk fat.

The concentration of myristic acid $\left(\mathrm{C}_{14: 0}\right)$ in the Reg-Milk (11.89 $\left.100 \mathrm{~g}^{-1} \mathrm{FA}\right)$ was significantly reduced $(P<0.01)$ in the Mod-Milk $(-27.6 \%)$ reaching a value

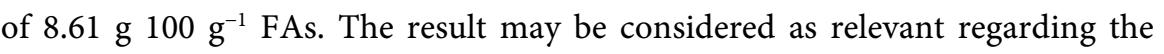
pro-atherogenic role of this FA [13]. The Mod-Milk showed significant decreases for the hypercholesterolemic fraction of milk fat averaging $32.2 \%$ for $\mathrm{C}_{12: 0}$, $27.6 \%$ for $\mathrm{C}_{14: 0}$ and $10.78 \%$ for $\mathrm{C}_{16: 0}$ (Table 2). When consumed in excess, these 
saturated FAs raise total plasma cholesterol and LDL-cholesterol [38] and therefore its decrease in the Mod-Milk (Table 2) and cheeses (Table 3 and Table 4) may be considered as a healthy result often observed after PUFAs supplementation to dairy cows [26] [39] [40]. It may be explained by synthesis of some trans FA at ruminal level that are inhibitors of key enzymes of mammary lipogenesis such as acetyl-CoA carboxylase [37].

As an associated result, the atherogenic index of milk decreased by $28.4 \%(P<$ 0.012 ) from 1.98 in Reg-Milk to 1.42 in the Mod-Milk. Significant decreases in

Table 3. Composition in some fatty acids of interest in the Por-Salut type cheese elaborated with the Ref-standar milk (Ref-PorSalut) and the milk obtained after cows supplementation with a blend of crude soybean oil sediment combined with fish oil (Mod-PorSalut).

\begin{tabular}{|c|c|c|c|c|}
\hline $\begin{array}{l}\text { Fatty Acid } \\
\text { (g/100g FA) }\end{array}$ & Ref-Por Salut & Mod-Por Salut & $\Delta \%^{(1)}$ & $P<$ \\
\hline $\mathrm{C}_{4: 0}$ & 1.85 & 1.60 & -13.50 & 0.000000 \\
\hline $\mathrm{C}_{6: 0}$ & 1.62 & 1.06 & -34.89 & 0.000000 \\
\hline $\mathrm{C}_{8: 0}$ & 1.20 & 0.62 & -48.00 & 0.000000 \\
\hline $\mathrm{C}_{10: 0}$ & 2.97 & 1.37 & -53.70 & 0.000000 \\
\hline $\mathrm{C}_{12: 0}$ & 3.47 & 1.69 & -51.01 & 0.000000 \\
\hline $\mathrm{C}_{14: 0}$ & 10.89 & 7.34 & -32.30 & 0.000000 \\
\hline $\mathrm{C}_{16: 0}$ & 28.81 & 23.55 & -18.10 & 0.000000 \\
\hline$\Sigma \mathrm{C} 12: 0-\mathrm{C} 16: 0$ & 43.16 & 32.59 & -24.51 & 0.000000 \\
\hline $\mathrm{C}_{18: 0}$ & 11.43 & 11.12 & -2.74 & 0.000056 \\
\hline trans-9 $\mathrm{C}_{18: 1}$ & 0.23 & 0.70 & 206.45 & 0.000000 \\
\hline trans-10 $\mathrm{C}_{18: 1}$ & 0.43 & 1.49 & 297.02 & 0.000000 \\
\hline trans-11 $\mathrm{C}_{18: 1}$ (vaccenic acid) & 1.46 & 5.89 & 303.26 & 0.000000 \\
\hline$c i s-9 \mathrm{C}_{18: 1}$ (oleic) & 20.54 & 23.49 & 14.32 & 0.000001 \\
\hline$c i s-9,-12 \mathrm{C}_{18: 2 \mathrm{n}-6}($ linoleic $)$ & 2.59 & 1.89 & -27.18 & 0.000002 \\
\hline cis-9, trans-11 C $18: 2$ (CLA) & 0.64 & 2.63 & 310.60 & 0.000000 \\
\hline cis-9, $-12,-15 \mathrm{C}_{18: 3}(\alpha$-linolenic) & 0.67 & 0.63 & -5.48 & 0.232846 \\
\hline C20:5 n-3 (EPA & 0.04 & 0.04 & 13.01 & 0.043951 \\
\hline C22:6 n-3 (DHA) & nd & nd & ND & \\
\hline Total SFA & 65.11 & 51.12 & -21.48 & 0.000000 \\
\hline Total MUFA & 27.40 & 38.10 & 39.04 & 0.000000 \\
\hline Total PUFA & 4.22 & 5.40 & 28.00 & 0.000000 \\
\hline Total omega- 6 & 2.78 & 1.94 & -29.97 & 0.000001 \\
\hline Total omega-3 & 0.79 & 0.75 & -4.65 & 0.194984 \\
\hline Omega $6 / 3$ ratio & 3.55 & 2.61 & -26.61 & 0.000579 \\
\hline Atherogenic Index & 2.45 & 1.34 & -45.35 & 0.000000 \\
\hline
\end{tabular}

${ }^{(1)}$ Relative changes (\%) compared to values observed in the Ref-PorSalut cheese. $(-)=$ decrease, $(+)=$ increase. nd $=$ not detected. 
Table 4. Composition in some fatty acids of interest in Cream-Cheese type elaborated with the Ref-standar milk (Ref-Cream) and the milk obtained after cows supplementation with a blend of crude soybean oil sediment combined with fish oil (Mod-Cream-Cheese).

\begin{tabular}{|c|c|c|c|c|}
\hline 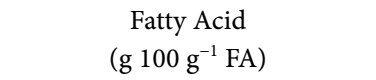 & Ref-Cream-Cheese & Mod-Cream-Cheese ${ }^{(1)}$ & $\Delta \%^{(2)}$ & $P<$ \\
\hline $\mathrm{C}_{4: 0}$ & 1.78 & 1.58 & -11.55 & 0.00103 \\
\hline $\mathrm{C}_{6: 0}$ & 1.36 & 1.11 & -18.70 & 0.00000 \\
\hline $\mathrm{C}_{8: 0}$ & 0.93 & 0.65 & -30.34 & 0.00000 \\
\hline $\mathrm{C}_{10: 0}$ & 2.19 & 1.42 & -34.86 & 0.00000 \\
\hline $\mathrm{C}_{12: 0}$ & 2.59 & 1.73 & -33.10 & 0.00000 \\
\hline $\mathrm{C}_{14: 0}$ & 9.54 & 7.47 & -21.61 & 0.00000 \\
\hline $\mathrm{C}_{16: 0}$ & 24.45 & 23.91 & -2.19 & 0.00008 \\
\hline$\Sigma \mathrm{C} 12: 0-\mathrm{C} 16: 0$ & 36.57 & 33.12 & -9.44 & 0.00000 \\
\hline $\mathrm{C}_{18: 0}$ & 13.15 & 10.89 & -17.22 & 0.00000 \\
\hline trans-9 $\mathrm{C}_{18: 1}$ & 0.41 & 0.69 & 67.36 & 0.00000 \\
\hline trans-10 $\mathrm{C}_{18: 1}$ & 1.18 & 0.99 & -16.17 & 0.04980 \\
\hline trans-11 $\mathrm{C}_{18: 1}$ (vaccenic acid) & 1.61 & 6.72 & 316.38 & 0.00000 \\
\hline cis-9 $\mathrm{C}_{18: 1}$ (oleic) & 25.59 & 22.64 & -11.54 & 0.00001 \\
\hline cis-9, $-12 \mathrm{C}_{18: 2 \mathrm{n}-6}$ (linoleic) & 3.20 & 1.70 & -46.84 & 0.00000 \\
\hline cis-9, trans-11 $\mathrm{C}_{18: 2}$ (CLA) & 0.81 & 2.80 & 244.57 & 0.00000 \\
\hline cis-9, $-12,-15 \mathrm{C}_{18: 3}(\alpha$-linolenic) & 0.48 & 0.56 & 18.01 & 0.00551 \\
\hline C20:5 n-3 (EPA) & 0.02 & 0.04 & 115.47 & 0.00055 \\
\hline C22:6 n-3 (DHA) & nd & nd & & \\
\hline Total SFA & 58.64 & 51.51 & -12.16 & 0.00000 \\
\hline Total MUFA & 34.35 & 37.63 & 9.56 & 0.00000 \\
\hline Total PUFA & 4.77 & 5.31 & 11.43 & 0.00000 \\
\hline Total omega- 6 & 3.39 & 1.75 & 26.96 & 0.00122 \\
\hline Total omega-3 & 0.54 & 0.69 & -48.32 & 0.00000 \\
\hline Omega $6 / 3$ ratio & 6.33 & 2.54 & -59.91 & 0.00003 \\
\hline Atherogenic Index & 1.70 & 1.39 & -18.61 & 0.00000 \\
\hline
\end{tabular}

${ }^{(1)}$ The cheese was added with cream from Ref-Milk to achieve the required standar typing. ${ }^{(2)}$ Relative changes $(\%)$ compared to values observed in the Ref-Cream cheese. $(-)=$ decrease, $(+)=$ increase. $n d=$ not detected.

the AI of milk from 1.92 to $1.47(-23 \%)$ were also obtained in cows supplemented with FO combined with vegetable oils [16].

Supplementation with oils rich in linoleic acid $\left(\mathrm{C}_{18: 2}\right)$ usually increases milk concentration of stearic acid $\left(\mathrm{C}_{18: 0}\right)$ as a consequence of supplementary $\mathrm{C}_{18: 2}$ and VA biohydrogenation [16]. In this trial, concentration of $\mathrm{C}_{18: 0}$ was not affected (Table 2) suggesting that the DHA contained in the FO was effective to attenuate biohydrogenation. A reduction of $\mathrm{C}_{18: 0}$ from 11.97 to $7.68{\mathrm{~g} 100 \mathrm{~g}^{-1} \mathrm{FA} \text { was }}$ 
observed after feeding $320 \mathrm{~g} \cdot$ day $^{-1}$ of FO to grazing dairy cows [16].

The basal concentration of some unhealthy trans FAs presented trace levels in

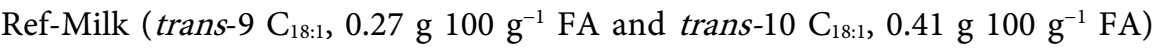
but increased after lipid supplementation (Table 2). However, the post-supplementation values observed (Table 2 ) in the Mod-Milk (0.76 and 1.21 g $100 \mathrm{~g}^{-1}$ FA respectively) would not present risks on the degree of ischemic heart disease in humans [19]. The presence of DHA in the FO may have contributed to maintaining low levels of trans-10 $\mathrm{C}_{18: 1}$ since the concentration of this FA tended to decrease after increasing FO intake mixed with sunflower oil [41].

After supplementary oil feeding, concentration of VA in Mod-Milk averaged

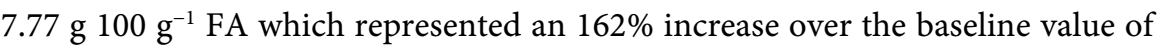

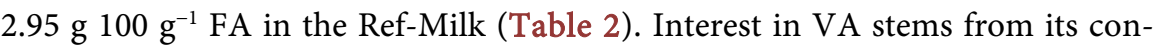
version to CLA inside the human body after interaction with a common human enzyme. In fact, it may exert healthy properties in itself as a bioactive lipid through a direct anticarcinogenic effect [42] or a mediated effect after its conversion to CLA at an estimated rate of $20 \%$ [25] by the activity of the $\Delta 9$-desaturase enzyme [43]. This metabolic pathway has proven to be an effective prevention of chemically induced cancer in rats [21] and increases the bioavailability of CLA in tissues [44]. In this context, the increase in VA in the Mod-Milk and cheeses may be considered as another relevant result for the consumer's health.

In the present study, VA represented $67.59 \%$ of the total trans- $\mathrm{C}_{181} \mathrm{FA}$ in the Ref-Milk remaining practically constant in the Mod-Milk (65.95\%) but slightly below the range of $77 \%$ to $82 \%$ observed in grazing dairy cows supplemented with a mix of soy and linseed oils [15]. Contribution of trans-9 $\mathrm{C}_{18: 1}$ in the total trans- $\mathrm{C}_{18: 1}$ was low in both, Ref- $(6.06 \%)$ and Mod-milks (6.46\%) and the same pattern was observed for the trans-10 $\mathrm{C}_{18: 1}$ (9.41\% and $10.27 \%$ respectively). These result suggest the absence of important ruminal deviations towards synthesis of unhealthy compounds (trans-9 and trans-10 $\mathrm{C}_{18: 1}$ ) after PUFAs supplementation. Significant deviations towards trans-9 and trans-10 $\mathrm{C}_{18: 1}$ FA were detected after supplying a mix of soybean oil and microalgae to confined dairy cows [28].

After VA, the natural CLA is the next most prevalent ruminant trans fat. The naturally occuring CLA and VA are widely recognized as a healthy type of trans FA that not share the potentially harmfull properties commonly associated with industrailly processed trans fat. Before supplementary PUFAs feeding, the basal concentration of natural CLA in Ref-Milk was relatively high (1.47 ${\left.\mathrm{g} 100 \mathrm{~g}^{-1} \mathrm{FA}\right)}$

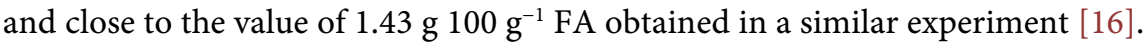

This high baseline milk CLA content would be the consequence of the high quality of the pastures and its content of alpha-linolenic acid $\left(\mathrm{C}_{18: 3}\right)$ promoting a high CLA content in milk even without supplementary PUFAs feeding or a moderate pasture intake. Results suggest that even in cases where high basal milk CLA content is observed, supplementation with PUFAs-rich oils is a highly effective and natural way to increase levels of milk CLA (Table 2). In the present 


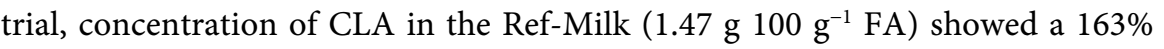
increase after PUFAs supplementation achieving an average value of $3.86 \mathrm{~g} 100$ $\mathrm{g}^{-1}$ FA in the Mod-Milk $(P<0.002)$. These levels of CLA resulted higher than those reported in the meta analysis of [36] after soybean oil supply (1.02 $\pm 0.36 \mathrm{~g}$ $\left.100 \mathrm{~g}^{-1} \mathrm{FA}\right)$ or that reported in confined dairy cows $(1.41 \pm 0.22)$ by [28] but

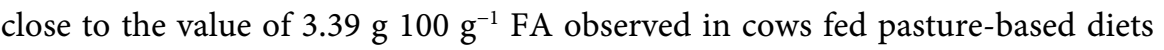
supplemented with sunflower and FO [16].

In the present work, the product/precursor ratio, (CLA/CLA + VA) resulted similar (0.33) before and after supplementary PUFA feeding suggesting that the activity of the mammary $\Delta 9$-desaturase remained unchanged. A similar ratio (0.33) was also observed after PUFAs supplementation to dairy cows [15] [31]. Since VA and CLA were correlated (Figure 1) and no association-risk for human health has been reported between both FA [19] these results can be counted as satisfactory.

Milk content of linoleic acid (cis-9, cis-12 $\mathrm{C}_{18: 2}$ ) decreased (-15.42\%) from a baseline value of $2.09 \mathrm{~g} 100^{-1}$ FA in Ref-Milk to $1.77 \mathrm{~g} 100^{-1}$ FA in the Mod-Milk (Table 2). These values were within the normal range of $2 \%-3 \%$ reported by

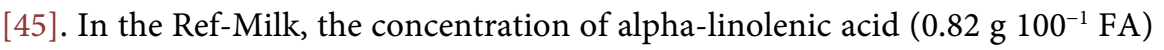
was above the range of $0.28-0.33 \mathrm{~g} 100^{-1} \mathrm{FA}$ observed in a previous trial [46] and decreased to $0.52 \mathrm{~g} 100^{-1} \mathrm{FA}$ after lipid supplementation (Table 2). The result can be explained in part by the biohydrogenation of $\mathrm{C}_{18: 3}$ to VA or other FA. The absence of an increase in alpha -linolenic acid was postulated even after supplementation with linseed oil at 3.2\% of the cow's DM intake [36].

Concentrations of EPA and DHA in milk were not increased after FO supply (Table 2) a result probably explained by the low FO dose used in this experiment $(0.1 \mathrm{~kg} / \mathrm{cow} /$ day $)$ or other metabolic sparing effects in the utilization of both essential FAs. The omega $6 / 3$ ratio resulted low in both milks (Table 2). An attempt is made to maintain an omega $6 / 3$ ratio between 10:1 to $5: 1$ or even lower in human diets to ensure a good metabolic balance. Since in the usual diet of humans the ratio is between 10 and 30, it can be considered that milk and cheeses can contribute to reducing this parameter.

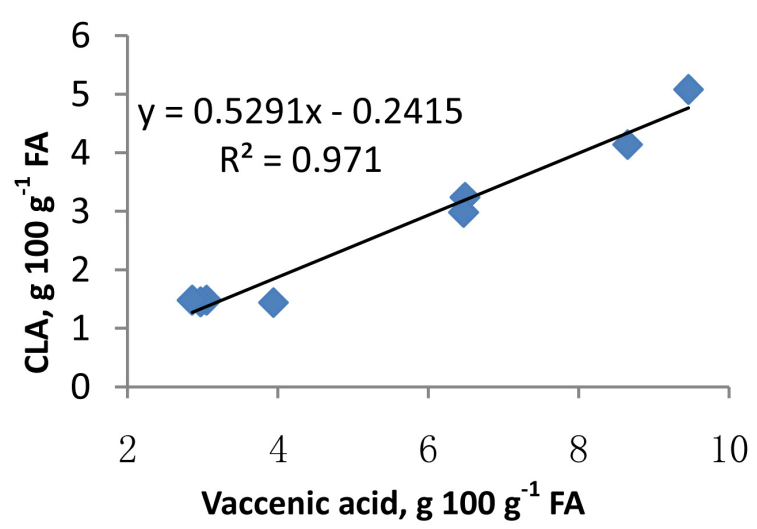

Figure 1. Relationship between the concentration of vaccenic acid (trans-11 $\mathrm{C}_{18} 1$ ) and conjugated linoleic acid (CLA, cis-9, trans-11 $\mathrm{C}_{18: 2}$ ) in milk. 
Milk content of oleic acid (cis-9 $\mathrm{C}_{18: 1}$ ) remained unchanged after lipid supplementation (Table 2). This FA from the omega-9 series is a component of the so-called "Mediterranean diet" and is mainly present in olive oil showing beneficial effects on the blood lipid profile and risk factors associated to cardiovascular diseases [47]. The increase in milk oleic acid content after supplementation of dairy cows with sunflower or soybean oils is a well documented result [27] [36] not observed in the present work despite the high content of oleic acid in the soybean oil (20.47\%).

In the present trial, MUFAs concentration increased (19.1\%) from a basal

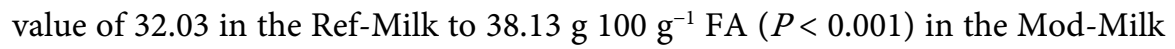
(Table 2). It has been postulated that MUFAs modulate blood pressure, improve insulin sensitivity and regulate circulating glucose levels [48].

\section{Fatty Acid Profile in Cheeses}

The cheese making technologies have a much smaller effect on FAs composition than the FAs profile of the milk of origin [49]. The correlation analysis performed showed a high correspondence $\left(\mathrm{R}^{2}=0.994, P<0.0001\right)$ between the Mod-Milk FA composition and the Mod-PorSalut type cheese made with it with very similar values for FA composition, aterogenicity index and total concentration of SFA, MUFA and PUFA (Figure 2 and Figure 3).

The differences in FAs composition and in parameters of interest of a variety of cheeses elaborated with the Ref- and the Mod milks are shown in Tables 3-8. In general terms, cheeses elaborated with the Mod-Milk showed important and healthy differences in their constitutive FAs compared to the standar cheeses made with the Ref-Milk. Comments and implications are conceptually equivalent to those discussed earlier for changes in milk FAs profile.

The peculiarities of the Por Salut type cheese are shown in Table 3.

As expected, the Mod-PorSalut cheese showed a significant decrease (-24.51\%) in the total concentration of the potentially atherogenic $F A s\left(\mathrm{C}_{12: 0}-\mathrm{C}_{16: 0}\right)$, total SFAs $(-21.48 \%)$ and the atherogenic index $(-45.35 \%)$ with a concomitant increase in

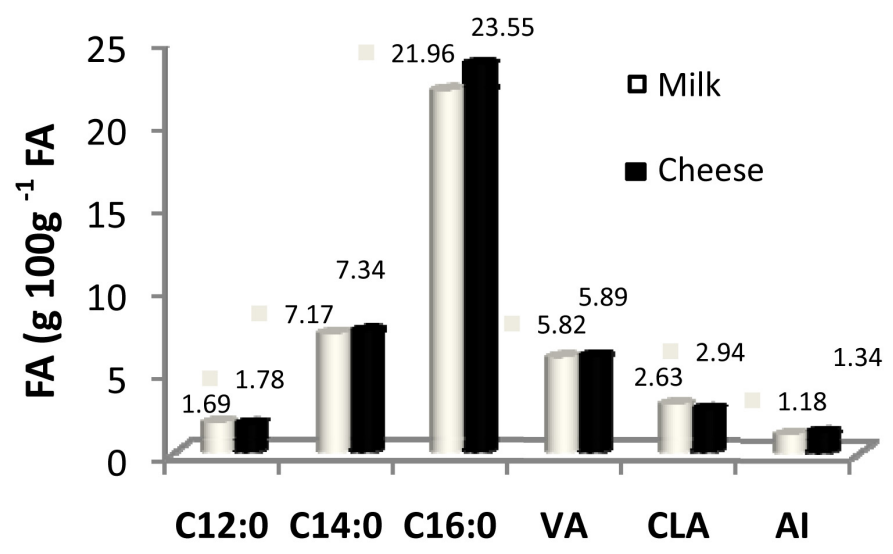

Figure 2. Concentration (g $100 \mathrm{~g}^{-1} \mathrm{FA}$ ) of some fatty acids of interest and atherogenic index (AI) of Mod-Milk and the Mod-Por Salut type cheese. 


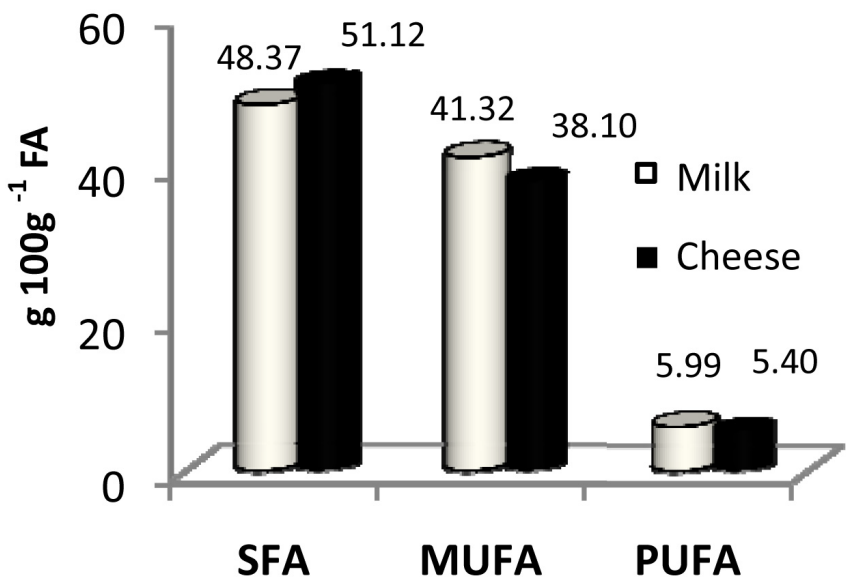

Figure 3. Concentration (g $100 \mathrm{~g}^{-1} \mathrm{FA}$ ) of saturated (SFAs), monounsaturated (MUFAs) and polyunsaturated (PUFAs) fatty acids in the Mod-Milk and in the Mod-PorSalut type cheese.

Table 5. Composition in some fatty acids of interest in the Mozarella type cheese elaborated with the Ref-standar milk (Ref-Mozarella) and the milk obtained after cows supplementation with a blend of crude soybean oil sediment combined with fish oil (Mod-Mozarella).

\begin{tabular}{|c|c|c|c|c|}
\hline $\begin{array}{c}\text { Fatty Acid } \\
\left(\mathrm{g} / 100 \mathrm{~g}^{-1} \mathrm{FA}\right)\end{array}$ & Ref-Mozzarella & Mod-Mozzarella & $\Delta \%{ }^{(1)}$ & $P<$ \\
\hline $\mathrm{C}_{4: 0}$ & 1.85 & 1.75 & -5.32 & 0.0097 \\
\hline $\mathrm{C}_{6: 0}$ & 1.62 & 1.22 & -25.10 & 0.0000 \\
\hline $\mathrm{C}_{8: 0}$ & 1.05 & 0.72 & -31.32 & 0.0002 \\
\hline $\mathrm{C}_{10: 0}$ & 2.85 & 1.57 & -44.86 & 0.0000 \\
\hline $\mathrm{C}_{12: 0}$ & 3.38 & 1.84 & -45.73 & 0.0000 \\
\hline $\mathrm{C}_{14: 0}$ & 11.08 & 7.53 & -32.03 & 0.0000 \\
\hline$C_{16: 0}$ & 29.37 & 23.79 & -18.99 & 0.0000 \\
\hline$\Sigma \mathrm{C} 12: 0-\mathrm{C} 16: 0$ & 43.83 & 33.16 & -24.35 & 0.0000 \\
\hline $\mathrm{C}_{18: 0}$ & 10.95 & 12.42 & 13.42 & 0.0244 \\
\hline trans-9 $\mathrm{C}_{18: 1}$ & 0.27 & 0.54 & 98.66 & 0.0003 \\
\hline trans-10 $\mathrm{C}_{18: 1}$ & 0.81 & 1.13 & 38.55 & 0.0053 \\
\hline trans-11 $\mathrm{C}_{18: 1}$ (vaccenic acid) & 1.22 & 5.18 & 324.50 & 0.0000 \\
\hline cis-9 $\mathrm{C}_{18: 1}$ (oleic) & 19.90 & 23.14 & 16.31 & 0.0000 \\
\hline cis-9, -12 C $18: 2 \mathrm{n}-6$ (linoleic) & 2.39 & 1.92 & -19.50 & 0.0000 \\
\hline cis-9, trans-11 $\mathrm{C}_{18: 2}$ (CLA) & 0.60 & 2.11 & 254.56 & 0.0000 \\
\hline cis-9, $-12,-15 \mathrm{C}_{18: 3}(\alpha$-linolenic) & 0.45 & 0.61 & 36.59 & 0.0028 \\
\hline C20:5 n-3 (EPA) & 0.02 & 0.05 & 103.33 & 0.0000 \\
\hline C22:6 n-3 (DHA) & 0.00 & 0.02 & & \\
\hline Total SFA & 64.91 & 53.71 & -17.27 & 0.0000 \\
\hline Total MUFA & 27.39 & 36.01 & 31.48 & 0.0000 \\
\hline
\end{tabular}




\section{Continued}

\begin{tabular}{|c|c|c|c|c|}
\hline Total PUFA & 3.68 & 4.92 & 33.86 & 0.0000 \\
\hline Total omega- 6 & 6.58 & 1.99 & -69.84 & 0.0000 \\
\hline Total omega-3 & 0.53 & 0.76 & 43.77 & 0.0005 \\
\hline Omega $6 / 3$ ratio & 4.79 & 2.62 & -45.29 & 0.0000 \\
\hline Atherogenic Index & 2.53 & 1.44 & -43.16 & 0.0000 \\
\hline
\end{tabular}

Table 6. Composition in some fatty acids of interest in Dambo type cheese elaborated with the Ref-standar milk (Ref-Dambo) and the milk obtained after cows supplementation with a blend of crude soybean oil sediment combined with fish oil (Mod-Dambo).

\begin{tabular}{|c|c|c|c|c|}
\hline $\begin{array}{c}\text { Fatty Acid } \\
\left(\mathrm{g} 100 \mathrm{~g}^{-1} \mathrm{FA}\right)\end{array}$ & Ref-Dambo & Mod-Dambo & $\Delta \%^{(1)}$ & $P<$ \\
\hline $\mathrm{C}_{4: 0}$ & 1.89 & 1.53 & -18.81 & 0.0013 \\
\hline $\mathrm{C}_{6: 0}$ & 1.51 & 0.94 & -37.73 & 0.0000 \\
\hline $\mathrm{C}_{8: 0}$ & 1.04 & 0.53 & -49.04 & 0.0000 \\
\hline $\mathrm{C}_{10: 0}$ & 2.41 & 1.10 & -54.46 & 0.0000 \\
\hline $\mathrm{C}_{12: 0}$ & 2.79 & 1.34 & -51.79 & 0.0000 \\
\hline $\mathrm{C}_{14: 0}$ & 9.79 & 6.02 & -38.52 & 0.0000 \\
\hline $\mathrm{C}_{16: 0}$ & 25.19 & 22.86 & -9.25 & 0.0000 \\
\hline$\Sigma \mathrm{C} 12: 0-\mathrm{C} 16: 0$ & 37.77 & 30.22 & -19.98 & 0.0000 \\
\hline $\mathrm{C}_{18: 0}$ & 12.54 & 13.13 & 4.72 & 0.0009 \\
\hline trans-9 $\mathrm{C}_{18: 1}$ & 0.31 & 0.68 & 115.26 & 0.0000 \\
\hline trans-10 $\mathrm{C}_{18: 1}$ & 0.78 & 1.34 & 72.86 & 0.0001 \\
\hline trans-11 $\mathrm{C}_{18: 1}$ (vaccenic acid) & 1.88 & 4.87 & 159.55 & 0.0000 \\
\hline cis-9 $\mathrm{C}_{18: 1}$ (oleic) & 23.07 & 26.39 & 14.37 & 0.0000 \\
\hline cis-9, $-12 \mathrm{C}_{18: 2 \mathrm{n}-6}$ (linoleic) & 2.63 & 2.11 & -19.65 & 0.0000 \\
\hline cis-9, trans-11 C $\mathrm{C}_{18: 2}$ (CLA) & 0.89 & 2.18 & 145.57 & 0.0000 \\
\hline$c i s-9,-12,-15 \mathrm{C}_{18: 3}(\alpha$-linolenic) & 0.56 & 0.59 & 5.65 & 0.2388 \\
\hline C20:5 n-3 (EPA) & 0.03 & 0.05 & 51.46 & 0.0133 \\
\hline C22:6 n-3 (DHA) & nd & 0.03 & & \\
\hline Total SFA & 59.98 & 50.33 & -16.10 & 0.0000 \\
\hline Total MUFA & 31.01 & 39.15 & 26.27 & 0.0001 \\
\hline Total PUFA & 4.35 & 5.16 & 18.60 & 0.0000 \\
\hline Total omega- 6 & 2.79 & 2.16 & -22.49 & 0.0000 \\
\hline Total omega-3 & 0.65 & 0.74 & 14.50 & 0.0033 \\
\hline Omega $6 / 3$ ratio & 4.31 & 2.91 & -32.42 & 0.0003 \\
\hline Atherogenic Index & 1.95 & 1.15 & -41.14 & 0.0000 \\
\hline
\end{tabular}

${ }^{(1)}$ Relative changes (\%) compared to values observed in the Ref-Dambo cheese. $(-)=$ decrease, $(+)=$ increase. nd $=$ not detected. 
Table 7. Composition in some fatty acids of interest in Sardo type cheese elaborated with the Ref-standar milk (Ref-Sardo) and the milk obtained after cows supplementation with a blend of crude soybean oil sediment combined with fish oil (Mod-Sardo).

\begin{tabular}{|c|c|c|c|c|}
\hline 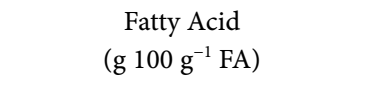 & Ref-Sardo & Mod-Sardo & $\Delta \%^{(1)}$ & $P<$ \\
\hline $\mathrm{C}_{4: 0}$ & 1.94 & 1.71 & -11.81 & 0.0287 \\
\hline $\mathrm{C}_{6: 0}$ & 1.52 & 1.13 & -25.79 & 0.0001 \\
\hline $\mathrm{C}_{8: 0}$ & 1.00 & 0.64 & -36.30 & 0.0000 \\
\hline $\mathrm{C}_{10: 0}$ & 2.21 & 1.31 & -40.48 & 0.0000 \\
\hline $\mathrm{C}_{12: 0}$ & 2.49 & 1.52 & -38.73 & 0.0000 \\
\hline $\mathrm{C}_{14: 0}$ & 9.28 & 6.63 & -28.50 & 0.0000 \\
\hline $\mathrm{C}_{16: 0}$ & 26.53 & 23.10 & -12.91 & 0.0000 \\
\hline$\Sigma \mathrm{C} 12: 0-\mathrm{C} 16: 0$ & 38.29 & 31.26 & -18.37 & 0.0000 \\
\hline $\mathrm{C}_{18: 0}$ & 13.29 & 12.34 & -7.14 & 0.0001 \\
\hline trans-9 $\mathrm{C}_{18: 1}$ & 0.23 & 0.60 & 165.44 & 0.0000 \\
\hline trans-10 $\mathrm{C}_{18: 1}$ & 0.36 & 1.12 & 208.93 & 0.0002 \\
\hline trans-11 $\mathrm{C}_{18: 1}$ (vaccenic acid) & 1.81 & 5.32 & 193.37 & 0.0000 \\
\hline cis-9 $\mathrm{C}_{18: 1}$ (oleic) & 24.21 & 25.50 & 5.31 & 0.0190 \\
\hline$c i s-9,-12 \mathrm{C}_{18: 2 \mathrm{n}-6}($ linoleic $)$ & 2.13 & 2.03 & -4.62 & 0.0717 \\
\hline cis-9, trans-11 $\mathrm{C}_{18: 2}$ (CLA) & 0.76 & 2.27 & 197.51 & 0.0000 \\
\hline cis-9, $-12,-15 \mathrm{C}_{18: 3}(\alpha$-linolenic) & 0.76 & 0.70 & -8.10 & 0.1374 \\
\hline C20:5 n-3 (EPA) & 0.06 & 0.05 & -17.57 & 0.0001 \\
\hline C22:6 n-3 (DHA) & $\mathrm{Nd}$ & 0.03 & & \\
\hline Total SFA & 61.19 & 51.23 & -16.28 & 0.0000 \\
\hline Total MUFA & 31.22 & 38.62 & 23.70 & 0.0002 \\
\hline Total PUFA & 3.97 & 5.29 & 33.11 & 0.0000 \\
\hline Total omega- 6 & 2.28 & 2.09 & -8.37 & 0.0099 \\
\hline Total omega-3 & 0.91 & 0.86 & -6.03 & 0.1633 \\
\hline Omega $6 / 3$ ratio & 2.49 & 2.43 & -2.44 & 0.5514 \\
\hline Atherogenic Index & 1.92 & 1.23 & -35.98 & 0.0000 \\
\hline
\end{tabular}

${ }^{(1)}$ Relative changes (\%) compared to values observed in the Ref-Sardo cheese. $(-)=$ decrease, $(+)=$ increase. nd $=$ not detected.

Table 8. Composition in some fatty acids of interest in provolone type cheese elaborated with the Ref-standar milk (Ref-Provolone) and the milk obtained after cows supplementation with a blend of crude soybean oil sediment combined with fish oil (Mod-Provolone).

\begin{tabular}{|c|c|c|c|c|}
\hline $\begin{array}{c}\text { Fatty Acid } \\
\left(\mathrm{g} 100 \mathrm{~g}^{-1} \mathrm{FA}\right)\end{array}$ & Ref-Provolone & Mod-Provolone & $\Delta \%^{(1)}$ & $P<$ \\
\hline $\mathrm{C}_{4: 0}$ & 1.67 & 1.66 & -0.70 & 0.8805 \\
\hline $\mathrm{C}_{6: 0}$ & 1.49 & 1.08 & -27.62 & 0.0155 \\
\hline $\mathrm{C}_{8: 0}$ & 1.06 & 0.61 & -42.46 & 0.0011 \\
\hline
\end{tabular}




\section{Continued}

\begin{tabular}{|c|c|c|c|c|}
\hline $\mathrm{C}_{10: 0}$ & 2.52 & 1.29 & -48.88 & 0.0001 \\
\hline $\mathrm{C}_{12: 0}$ & 2.96 & 1.56 & -47.27 & 0.0000 \\
\hline $\mathrm{C}_{14: 0}$ & 10.11 & 6.72 & -33.52 & 0.0000 \\
\hline $\mathrm{C}_{16: 0}$ & 27.23 & 22.70 & -16.65 & 0.0000 \\
\hline$\Sigma \mathrm{C} 12: 0-\mathrm{C} 16: 0$ & 40.30 & 30.98 & -23.13 & 0.0000 \\
\hline $\mathrm{C}_{18: 0}$ & 9.88 & 11.97 & 21.24 & 0.0674 \\
\hline trans $-9 \mathrm{C}_{18: 1}$ & 0.30 & 0.71 & 137.33 & 0.0000 \\
\hline trans-10 $\mathrm{C}_{18: 1}$ & 0.65 & 1.29 & 99.18 & 0.0041 \\
\hline trans-11 $\mathrm{C}_{18: 1}$ (vaccenic acid) & 2.57 & 6.01 & 134.10 & 0.0000 \\
\hline cis-9 $\mathrm{C}_{18: 1}$ (oleic) & 21.74 & 24.39 & 12.20 & 0.0001 \\
\hline cis-9, -12 $\mathrm{C}_{18: 2 \mathrm{n}-6}$ (linoleic) & 2.08 & 2.02 & -3.09 & 0.3432 \\
\hline cis-9, trans-11 $\mathrm{C}_{18: 2}$ (CLA) & 1.20 & 2.51 & 108.38 & 0.0000 \\
\hline cis-9, $-12,-15 \mathrm{C}_{18: 3}(\alpha$-linolenic) & 0.80 & 0.64 & -19.20 & 0.0030 \\
\hline C20:5 n-3 (EPA & 0.05 & 0.04 & -19.79 & 0.0036 \\
\hline C22:6 n-3 (DHA) & nd & 0.02 & & \\
\hline Total SFA & 59.77 & 50.36 & -15.76 & 0.0010 \\
\hline Total MUFA & 30.14 & 38.82 & 28.79 & 0.0000 \\
\hline Total PUFA & 4.38 & 5.43 & 24.20 & 0.0000 \\
\hline Total omega- 6 & 5.69 & 2.07 & -63.63 & 0.0000 \\
\hline Total omega-3 & 0.93 & 0.79 & -15.39 & 0.0025 \\
\hline Omega $6 / 3$ ratio & 2.39 & 2.63 & 9.94 & 0.0794 \\
\hline Atherogenic Index & 2.12 & 1.23 & -42.17 & 0.0000 \\
\hline
\end{tabular}

${ }^{(1)}$ Relative changes expressed as \% of values observed in the Ref-Provolone cheese. $(-)=$ decrease, $(+)=$ increase. nd $=$ not detected.

healthy FAs as VA (303\%) and cis-9, trans-11 CLA (311\%). The lower Omega $6 / 3$ ratio and the increase in the concentration of MUFAs and PUFAs potentially improve the healthy value of the Mod-PorSalut cheese.

The results obtained in the case of Cream-Cheese type were comparable to those described for the PorSalut one and confirm the difference between the Ref and the Mod product elaborated with the enriched CLA milk. The increase in

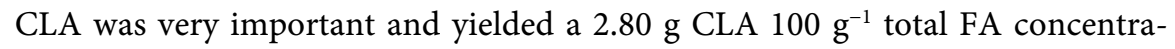
tion. Parameters for the Mozzarella type cheese are presented in Table 5.

Parameters and FA profile obtained in the Dambo type cheese is shown in Table 6.

Parameters of interest in the Sardo-type Cheese are shown in Table 7.

The results obtained in the Provolone type cheese are presented in Table 8.

Total cholesterol concentration in the Ref- or Mod-cheeses were very close and highly correlated $\left(\mathrm{R}^{2}=0.96\right.$, Figure 4$)$ varying according cheese type.

Except in the case of the Por-Salut type, a lower average colesterol level $(-0.11$ 
$\mathrm{mg} / 100 \mathrm{~g}, P<0.03)$ was observed in the Mod-products adding another healthy property to the enriched-CLA cheeses (Table 9 ).

Fat content in the different cheese-types and saturated fat (SF) per serving (30 $\mathrm{g}$ cheese) are shown in Table 10.

As the combined effect of a lower fat and SF contents, the Mod-Por Salut cheese was very efficient to reduce SF intake per serving followed by the Sardo, Mozzarella, Provolone, Cream and Dambo type cheeses (Table 10).

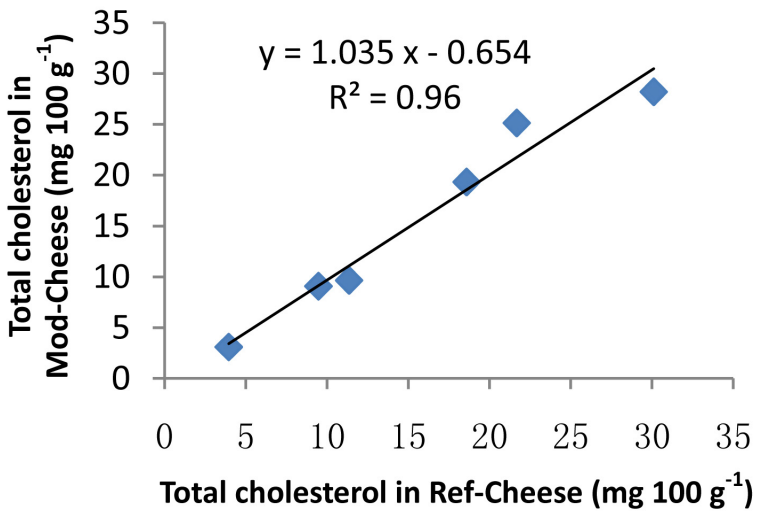

Figure 4. Relationship in total colesterol concentration (mg/100g) between cheeses elaborated with the Ref-standar milk (Ref-Cheese) and the milk obtained after cows supplementation with a blend of crude soybean oil sediment combined with fish oil (Mod-Cheese).

Table 9. Cholesterol levels (mg $100 \mathrm{~g}^{-1}$ ) in cheeses elaborated with the Ref-standar milk (Ref-Cheese) and the milk obtained after cows supplementation with with a blend of crude soybean oil sediment combined with fish oil (Mod-Cheese).

\begin{tabular}{cccc}
\hline Cheese type & Ref-Cheese & Mod-Cheese & $\Delta \%^{(1)}$ \\
Sardo & 30.1 & 28.2 & -6.31 \\
Dambo & 18.58 & 19.33 & +4.04 \\
Cremoso Light & 9.47 & 9.07 & -4.22 \\
Por-Salut (without salt) & 21.67 & 25.14 & +16.01 \\
Mozzarella & 11.35 & 9.65 & -14.98 \\
Mozzarella-Light & 3.95 & 3.1 & -21.52 \\
\hline
\end{tabular}

${ }^{(1)}$ Relative changes expressed as \% of values observed in the Ref cheese. $(-)=$ decrease, $(+)=$ increase.

Table 10. Fat content and saturated fat (SF) intake per serving (30 g) of cheeses elaborated with the Ref-milk and the milk obtained after cows supplementation with a blend of crude soybean oil sediment combined with fish oil (Mod-Cheeses).

\begin{tabular}{ccccc}
\hline Cheese type & $\begin{array}{c}\text { Fat content } \\
\left(\mathrm{g} 100 \mathrm{~g}^{-1}\right)\end{array}$ & $\begin{array}{c}\text { SF content } \\
\left(\mathrm{g} 100 \mathrm{~g}^{-1} \text { cheese }\right)\end{array}$ & $\begin{array}{c}\text { SF intake } \\
\left(\mathrm{g} \mathrm{serving}^{-1}\right)\end{array}$ & $\begin{array}{c}\text { Reduction } \\
(\%)^{(1)}\end{array}$ \\
\hline Ref-PorSalut & 18.04 & 11.06 & 3.32 & -41.94 \\
Mod-Porsalut & 13.34 & 6.42 & 1.93 & \\
Ref-Provolone & 19.82 & 11.15 & 3.35 & -6.14 \\
Mod-Provolone & 22.08 & 10.47 & 3.14 & \\
\hline
\end{tabular}




\section{Continued}

\begin{tabular}{ccccc}
\hline Ref-Sardo & 23.96 & 13.80 & 4.14 & -8.66 \\
Mod-Sardo & 26.14 & 12.61 & 3.78 & \\
Ref-Dambo & 20.59 & 11.63 & 3.49 & -0.97 \\
Mod-Dambo & 24.30 & 11.52 & 3.45 & \\
Ref-Mozzarella & 22.40 & 13.69 & 4.11 & -7.17 \\
Mod-Mozarella & 25.13 & 12.71 & 3.81 & \\
Ref-Creamcheese & 19.40 & 10.71 & 3.21 & -3.24 \\
Mod-Creamcheese & 21.37 & 10.36 & 3.11 & \\
\hline
\end{tabular}

${ }^{(1)}$ Relative change compared to the Ref cheese.

Table 11. Conjugated linoleic acid (CLA) content and intake per serving (30 g) of cheeses elaborated with the Ref-milk and the milk obtained after cows supplementation with a blend of crude soybean oil sediment combined with fish oil (Mod-Cheese).

\begin{tabular}{ccccc}
\hline Cheese type & $\begin{array}{c}\text { CLA } \\
\left(\mathrm{g} 100 \mathrm{~g}^{-1} \text { cheese }\right)\end{array}$ & $\begin{array}{c}\text { CLA intake } \\
\left(\mathrm{g} \mathrm{serving}^{-1}\right)\end{array}$ & $\begin{array}{c}\text { Antitumoral } \\
\text { Prevention (\%) }\end{array}$ & $\begin{array}{c}\text { Atherogenic } \\
\text { Prevention (\%) }\end{array}$ \\
\hline Ref-PorSalut & 0.11 & 0.03 & 4.08 & 13.04 \\
Mod-Porsalut & 0.33 & 0.10 & 12.39 & 39.64 \\
Ref-Provolone & 0.22 & 0.07 & 8.40 & 26.87 \\
Mod-Provolone & 0.52 & 0.16 & 19.57 & 62.62 \\
Ref-Sardo & 0.17 & 0.05 & 6.43 & 20.57 \\
Mod-Sardo & 0.56 & 0.17 & 20.95 & 67.04 \\
Ref-Dambo & 0.17 & 0.05 & 6.47 & 20.70 \\
Mod-Dambo & 0.50 & 0.15 & 18.70 & 59.85 \\
Ref-Mozzarella & 0.13 & 0.04 & 4.75 & 15.19 \\
Mod-Mozarella & 0.50 & 0.15 & 18.72 & 59.91 \\
Ref-Creamcheese & 0.15 & 0.04 & 5.55 & 17.75 \\
Mod-Creamcheese & 0.56 & 0.17 & 21.13 & 67.61 \\
\hline
\end{tabular}

${ }^{(1)}$ CLA supply per serving as $\%$ of the estimated antitumoral $\left(0.8 \mathrm{~g} \mathrm{day}^{-1}\right)$ and antiatherogenic $\left(0.25 \mathrm{~g} \mathrm{day}^{-1}\right)$ CLA preventive doses [4].

The estimation of the achievable CLA intake supplied from cheeses elaborated with the Ref- and the Mod-milks is shown in Table 11.

In this trial, at the serving intake of $30 \mathrm{~g}$, the modified CLA rich cheeses covered from $68 \%$ to $40 \%$ of the atherogenic and from $21 \%$ to $12 \%$ of the preventive antitumoral doses suggested in [4] ranking as CreamCheese $>$ Sardo $>$ Mozzarella $>$ Provolone $>$ Dambo $>$ PorSalut type cheeses.

It is worthly to note that the estimated CLA intake per serving (Table 11) was calculated computing only the direct exogenous CLA supply from the diet. In addition to this direct CLA intake, the extra endogenous CLA supply after the bioconversion of VA should be considered to estimate total CLA availability in human tissues [25] [50]. In this trial, at the $20 \%$ rate of endogenous bioconversion 
of the VA contained in cheese into CLA [25] [50], it can be calculated that total CLA availability per cheese serving increased over $1.43( \pm 0.03)$ to $1,47( \pm 0,02)$ times overvalues presented in Table 11 for the reference and modified cheeses respectively. The estimation was near to the 1.5 average increase factor proposed by [25] [50] resulting in a substantially higher availability of CLA to humans. For instance, at the $0.41 \mathrm{~g}$ of VA provided by a serving ( $30 \mathrm{~g}$ ) of the Cream-type cheese, some additional $0.081 \mathrm{mg}$ of endogenously formed CLA would be available increasing the net CLA availability up to $250 \mathrm{mg}$ instead of the calculated $170 \mathrm{mg}$ per serving proposed in Table $11(+47.6 \%)$. Finally, it may be interesting to determine if CLA may be looked at as a marginal missing nutrient in present food sources as proposed in [50]. This authors also suggested that future research will need to elucidate if the natural CLA should be considered to be a marginally missing or as emi-essential nutrient in the human diet because of its lower than normally achievable intakes [50]. The actual intake of CLA and VA may be also reduced by the current dietary recommendations of "energy-restricted dieting", "fat free" claims or food practices using skimmed milk. Are consideration of recommendations on milk fatintake and whole fat dairy products merits to be reconsidered.

\section{Conclusion}

The findings confirmed that bovine milk fat composition is responsive to dietary manipulation and support accumulating evidence showing that supplementary PUFAs feeding to dairy cows are an effective way to modify the content of fatty acids of benefit to human health in milk and cheese with health-boosting properties. Feeding PUFAs rich oils rich is a feasible dietary strategy to improve beneficial FAs contents of milk and milk products. The changes obtained were compatible with the objective of reconsidering the healthy value of dairy products revitalizing its image for the consumer. The beneficial dyslipidemic properties induced consisted in a reduction in total saturated fat and the potentially atherogenic FAs with a concomitant decrease in the atherogenicity index. These changes were coupled to an important increase in bioactive FA such as VA and natural CLA. The healthy properties observed in milk were recovered in cheeses so that their concentrations in the modified milk and cheeses were higher than the levels typically available in the regular products. The intake of these naturally modified dairy foods may help fight or prevent incidence of non-communicable, cardiovascular and chronic diseases. Total cholesterol content in regular and natural modified cheeses showed a similar pattern but excepting in the case of the Por-Salut type cheese, it tended to be lower in the modified natural CLA products adding another healthy property to the enriched-CLA cheeses. According to the antitumoral or the antiatherogenic prevention, CLA enriched cheeses ranked as CreamCheese $>$ Sardo $>$ Mozzarella $>$ Provolone $>$ Dambo $>$ PorSalut type in changes that are valuable for human nutrition. For the future, the efforts must progress in the context of overall production, marketing and 
regulatory strategies that may allow any explanation of VA and CLA benefits to the consumer.

\section{Acknowledgements}

This work was partially supported by CDS and the National Institute of Agricultural Technology (INTA), Argentine. We thank the staff of "Gacef Farm" for the collaboration in animal care and management and to CDS (LacNat cheeses) for cheese manufacturing.
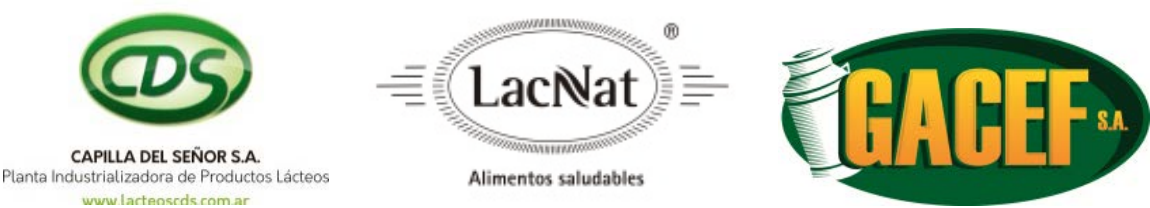

\section{Conflicts of Interest}

The authors declare no conflicts of interest regarding the publication of this paper.

\section{References}

[1] Chilliard, Y., Ferlay, A., Mansbridge, R.M. and Doreau, M. (2000) Ruminant Milk Fat Plasticity: Nutritional Control of Saturated, Polyunsaturated, Trans and Conjugated Fatty Acids. Annales de Zootechnie, 49, 181-205. https://doi.org/10.1051/animres:2000117

[2] Williams, C.M. (2000) Dietary Fatty Acids and Human Health. Annales de Zootechnie, 49, 165-180. https://doi.org/10.1051/animres:2000116

[3] Jensen, R.G. (2002) Invited Review: The Composition of Bovine Milk Lipids: January 1995 to December 2000. Journal of Dairy Science, 85, 295-350. https://doi.org/10.3168/jds.S0022-0302(02)74079-4

[4] Gagliostro, G.A. (2004) Nutritional Control of Conjugated Linoleic Acid (CLA) Content in Milk and Natural Functional Foods. Effects on Human Health. Revista Argentina de Produción Animal, 24, 113-136.

[5] Chilliard, Y., Rouel, J. and Leroux, C. (2006) Goat's Alpha-s1 Casein Genotype Influences Its Milk Fatty Acid Composition and Delta-9 Desaturation Ratios. Animal Feed Science and Technology, 131, 474-487. https://doi.org/10.1016/j.anifeedsci.2006.05.025

[6] Givens, D.I. and Shingfield, K.J. (2005)) Optimising Dairy Milk Fatty Acid Composition. In: Williams, C. and Buttriss, J., Eds., Improving the Fat Content of Foods, Woodhead Publishing Ltd., Cambridge, Chapter 11, 252-280. https://doi.org/10.1533/9781845691073.2.252

[7] Legrand, P. (2001) ANCs for Fat. Science Aliments, 21, 348-360.

[8] Knopp, R.H. and Retzlaff, B.M. (2004) Saturated Fat Prevents Coronary Artery Disease? An American Paradox. American Journal of Clinical Nutrition, 80, 1102-1103. https://doi.org/10.1093/ajcn/80.5.1102

[9] Hu, F.B., Manson, J.E. and Willet, W.C. (2001) Types of Dietary Fat and Risk Coronary Heart Disease: A Critical Review. Journal of the American College of Nutrition, 20, 5-19. https://doi.org/10.1080/07315724.2001.10719008 
[10] Siri-Tarino, P.W., Sun, Q., Hu, F.B. and Krauss, R.M. (2010) Saturated Fat, Carbohydrate, and Cardiovascular Disease. American Journal of Clinical Nutrition, 91, 502-509. https://doi.org/10.3945/ajcn.2008.26285

[11] Livingstone, K.M., Lovegrove, J.A. and Givens, D.I. (2012) The Impact of Substituting SFA in Dairy Products with MUFA or PUFA on CVD Risk: Evidence from Human Intervention Studies. Nutrition Research Reviews, 25, 193-206. https://doi.org/10.1017/S095442241200011X

[12] HLSG (2013) Saturated Fat Reduction. Am J Public Health, 103, e31-e42. https://www.ncbi.nlm.nih.gov/pmc/articles/PMC3966685/

[13] Ulbritch, T.L. and Southgate, D.A.T. (1991) Coronary Heart Disease: Seven Dietary Factors. The Lancet, 338, 985-992. https://doi.org/10.1016/0140-6736(91)91846-M

[14] Gagliostro, G.A. (2004) Nutritional Control of Conjugated Linoleic Acid (CLA) Content in Milk and Its Presence in Functional Natural Foods. 2. Production of High Cow's Milk CLA. Revista Argentina de Produccion Animal, 24, 137-163.

[15] Antonacci, L.E., Gagliostro, G.A., Cano, A.V. and Bernal, C.A. (2017) Effects of Feeding Combinations of Soybean and Linseed Oils on Productive Performance and Milk Fatty Acid Profile in Grazing Dairy Cows. Agricultural Sciences, 8, 984-1002. https://doi.org/10.4236/as.2017.89072

[16] Gagliostro, G.A., Garciarena, D.A., Rodriguez, M.A. and Antonacci, L.E. (2017) Feeding Polyunsaturated Supplements to Grazing Dairy Cows Improve the Healthy Value of Milk Fatty Acids. Agricultural Sciences, 8, 759-782. https://doi.org/10.4236/as.2017.88057

[17] Ness, A.R., Smith, G.D. and Hart, C. (2001) Milk, Coronary Heart Disease and Mortality. Journal of Epidemiology and Community Health, 55, 379-382. https://doi.org/10.1136/jech.55.6.379

[18] Smit, L.A., Baylin, A. and Campos, H. (2010) Conjugated Linoleic Acid in Adipose Tissue and Risk of Myocardial Infarction. American Journal of Clinical Nutrition, 92, 34-40. https://doi.org/10.3945/ajcn.2010.29524

[19] Roy, A., Chardigny, J.M., Bauchart, D., Ferlay, A., Lorenz, S., Durand, D., Duffart, D., Faulconnier, Y., Sebedio, J.L. and Chilliard, Y. (2007) Butters Rich Either in Trans-10-C18:1 or in Trans-11-C18:1 plus cis-9-trans11 CLA Differentially Affect Plasma Lipids and Aortic Fatty Streak in Experimental Atherosclerosis in Rabbits. Animal, 1, 467-476. https://doi.org/10.1017/S175173110770530X

[20] Parodi, P.W. (1999) Conjugated Linoleic Acid and Other Anticarcinogenic Agents of Bovine Milk Fat. Journal of Dairy Science, 82, 1339-1349. https://doi.org/10.3168/jds.S0022-0302(99)75358-0

[21] Banni, S., Angioni, E., Murru, E., Carta, G., Melis, M.P., Bauman, D., Dong, Y. and Ip, C. (2001) Vaccenic Acid Feeding Increases Tissue Levels of Conjugated Linoleic Acid and Suppreses Development of Remalignant Lesions in Rat Mammary Gland. Nutrition and Cancer, 41, 91-97. https://doi.org/10.1080/01635581.2001.9680617

[22] Ip, M.M., Masso-Welch, P.A. and Ip, C. (2003) Prevention of Mammary Cancer with Conjugated Linoleic Acid: Role of the Stroma and the Epithelium. Journal of Mammary Gland Biology and Neoplasia, 8, 103-118. https://doi.org/10.1023/A:1025739506536

[23] Sofi, F., Buccioni, A., Cesari, F., Gori, A.M., Minieri, S., Mannini, L., Casini, A., Gensini, G.F., Abbate, R. and Antogiovanni, M. (2010) Effects of a Dairy Product (Pecorino Cheese) Naturally Rich in cis-9, trans-11 Conjugated Linoleic Acid on Lipid, Inflammatory, and Haemorheological Variables: A Dietary Intervention 
Study. Nutrition Metabolism and Cardiovascular Diseases, 20, 117-124. https://doi.org/10.1016/j.numecd.2009.03.004

[24] Stanton, C., Murphy, J., McGrath, E. and Devery, R. (2003) Animal Feeding Strategies for Conjugates Linoleic Acid Enrichment of Milk. In: Sebedio, J.L., Christie, W.W. and Adloff, R., Eds., Advances in Conjugated Linoleic Acid in Food, AOCS Press, Champaign, 123-145.

[25] Turpeinen, A.M., Mutanen, M., Aro, A., Salminen, I., Basu, S., Palmquist, D.L. and Griinari, J.M. (2002) Bioconversion of Vaccenic Acid to Conjugated Linoleic Acid in Humans. American Journal of Clinical Nutrition, 76, 504-510. https://doi.org/10.1093/ajcn/76.3.504

[26] AbuGhazaleh, A. and Jenkins, T.C. (2004) Short Communication: Docosahexaenoic Acid Promotes Vaccenic Acid Accumulation in Mixed Rumen Cultures When Incubated with Linoleic Acid. Journal of Dairy Science, 87, 1047-1050. https://doi.org/10.3168/jds.S0022-0302(04)73250-6

[27] Chilliard, Y., Martin, C., Rouel, J. and Doreau, M. (2009) Milk Fatty Acids in Dairy Cows Fed Whole Crude Linseed, Extruded Linseed, or Linseed Oil, and Their Relationship with Methane Output. Journal of Dairy Science, 92, 5199-5211. https://doi.org/10.3168/jds.2009-2375

[28] Gagliostro, G.A., Antonacci, L.E., Perez, C.D., Rossetti, L. and Carabajal, A. (2018) Improving the Quality of Milk Fatty Acid in Dairy Cows Supplemented with Soybean Oil and DHA-Micro Algae in a Confined Production System. Agricultural Sciences, 9, 1115-1130. https://doi.org/10.4236/as.2018.99078

[29] Schroeder, G.F., Gagliostro, G.A., Bargo, F., Delahoy, J.E. and Muller, L.D. (2004) Effects of Fat Supplementation on Milk Production and Composition by Dairy Cows on Pasture: A Review. Livestock Production Science, 86, 1-18. https://doi.org/10.1016/S0301-6226(03)00118-0

[30] Piperova, L.L., Teter, B.B., Bruckental, I., Sampugna, J., Mills, S.E., Yurawecz, M.P., Fritsche, J., Ju, K. and Erdman, R.A. (2000) Mammary Lipogenic Enzyme Activity, Trans Fatty Acids and Conjugated Fatty Acids Are Altered in Lactating Dairy Cows Fed a Milk-Fat Depressing Diet. Journal of Nutrition, 130, 2568-2574. https://doi.org/10.1093/jn/130.10.2568

[31] Griinari, J.M. and Bauman, D.E. (2006) Milk Fat Depression: Concepts, Mechanisms and Management Applications. Ruminant Physiology: Digestion, Metabolism and Impact of Nutrition on Gene Expression, Immunology and Stress. Academic Publishers, Wageningen, 389-417.

[32] Martinez, M.G. (2010) Modulation of the Fatty Acid Composition of Bovine and Caprine Milk through Supplementation with Soybean and Fish Oil. Master Science Thesis, Faculty of Agrarian Sciences, National University of Mar de Plata, Argentina, $130 \mathrm{p}$.

[33] Bargo, F., Muller, L.D., Kolver, E.S. and Delahoy, J.E. (2003) Invited Review: Production and Digestion of Supplemented Dairy Cows on Pasture. Journal of Dairy Science, 86, 1-42. https://doi.org/10.3168/jds.S0022-0302(03)73581-4

[34] Gagliostro, G.A. and Chilliard, Y. (1992) Use of Protected Lipids in Dairy Cow Nutrition. I. Effects on the Production and Composition of Milk, and on Intake of Dry Matter and Energy. Revista Argentina de Produccion Animal, 12, 1-15.

[35] Wu, Z. and Huber, J.T. (1994) Relationship between Dietary Fat Supplementation and Milk Protein Concentration in Lactating Cows: A Review. Livestock Production Science, 39, 141-155. https://doi.org/10.1016/0301-6226(94)90180-5 
[36] Glasser, F., Ferlay, A. and Chilliard, Y. (2008) Oilseed Lipid Supplements and Fatty Acid Composition of Cow Milk: A Meta-Analysis. Journal of Dairy Science, 91, 4687-4703. https://doi.org/10.3168/jds.2008-0987

[37] Chilliard, Y. and Ferlay, A. (2004) Dietary Lipids and Forages Interactions on Cows and Goat Milk Acid Composition and Sensory Properties. Reproduction Nutrition Development, 44, 467-492. https://doi.org/10.1051/rnd:2004052

[38] Schrezenmeir, J. and Jagla, A. (2000) Milk and Diabetes. Journal of the American College of Nutrition, 19, 176-190. https://doi.org/10.1080/07315724.2000.10718087

[39] Zheng, H.C., Liu, J.X., Yao, J.H., Yuan, Q., Ye, H.W., Ye, J.A. and Wu, Y.M. (2005) Effects of Dietary Sources of Vegetable Oils on Performance of High-Yielding Lactating Cows and Conjugated Linoleic Acids in Milk. Journal of Dairy Science, 88, 2037-2042. https://doi.org/10.3168/jds.S0022-0302(05)72880-0

[40] Huang, Y., Schoonmaker, J.P., Bradford, B.J. and Beitz, D.C. (2008) Response of Milk Fatty Acid Composition to Dietary Supplementation of Soy Oil, Conjugated Linoleic Acid, or Both. Journal of Dairy Science, 91, 260-270. https://doi.org/10.3168/jds.2007-0344

[41] Palmquist, D. and Griinari, M. (2006) Milk Fatty Acid Composition in Response to Reciprocal Combinations of Sunflower and Fish Oils in the Diet. Animal Feed Science and Technology, 131, 358-369. https://doi.org/10.1016/j.anifeedsci.2006.05.024

[42] Awad, A.B., Hermann, T., Fink, C.S. and Horvath, P.J. (1995) 18:1 n7 Fatty Acids Inhibit Growth and Decreased Inositol Phosphate Release in HT-29 Cells Compared to n-9 Fatty Acids. Cancer Letters, 91, 55-61. https://doi.org/10.1016/0304-3835(95)03725-C

[43] Parodi, P.W. (2003) Conjugated Linoleic Acid in Food. In: Sebedio, J.L., Christie, W.W. and Adloff, R., Eds., Advances in Conjugated Linoleic Acid in Food, Volume 2, AOCS Press, Champaign, 101-122. https://doi.org/10.1201/9781439822166.ch8

[44] Siurana, A. and Calsamiglia, S. (2016) A Metaanalysis of Feeding Strategies to Increase the Content of Conjugated Linoleic Acid (CLA) in Dairy Cattle Milk and the Impact on Daily Human Consumption. Animal Feed Science and Technology, 217, 13-26. https://doi.org/10.1016/j.anifeedsci.2016.04.013

[45] Chilliard, Y., Gasser, G., Enjalbert, F., Ferlay, A., Bocquier, F. and Schimidely, P.H. (2007) Conference: Recent Results on the Effects of Nutrition on Fatty Acid Composition of Cow, Goat and Sheep Milk. Revista Argentina de Produccion Animal, 27, 197-213.

[46] Gagliostro, G.A., Antonacci, L., Espiñeira, M., Williner, M.R. and Bernal, C.A. (2013) Poliunsaturated Fatty Acid Supplementation and Milk Fatty Acid Profile in Dairy Cows. Revista Argentina de Produccion Animal, 33, 159.

[47] Mensink, R.P., Zock, P.L., Kester, A.D. and Katan, M.B. (2003) Effects of Dietary Fatty Acids and Carbohydrates on the Ratio of Serum Total to HDL Cholesterol and on Serum Lipids and Apolipoproteins: A Meta Analysis of 60 Controlled Trials. American Journal of Clinical Nutrition, 77, 1146-1155. https://doi.org/10.1093/ajen/77.5.1146

[48] Gullingham, L.G., Harris-Janz, S. and Jones, P.J. (2011) Dietary Monounsaturated Fatty Acids Are Protective against Metabolic Syndrome and Cardiovascular Disease Risk Factors. Lipids, 46, 2019-2228. https://doi.org/10.1007/s11745-010-3524-y

[49] Ferlay, A., Gaborit, P., Raynal-Ljutovac, K., Rouel, J., Lauret, A. and Chilliard, Y. (2005) Effects of Different Cheese-Making Technologies on the Composition of 
Fatty Acids of Nutritional Value in Goat Cheeses. Rencontres Recherches Ruminants, 12, 45 .

[50] van Wijlen, J.R.P. and Colombani, P.C. (2010) Grass-Based Ruminant Production Methods and Human Bioconversion of Vaccenic Acid with Estimations of Maximal Dietary Intake of Conjugated Linoleic Acids. International Dairy Journal, 20, 433-448. 